\title{
DASS Application: Increasing the Quality of Academic Services for Lecturers and Students
}

\author{
Syaharuddin $^{1}$, Abdillah ${ }^{2}$, Kiki Riska AK ${ }^{3}$, Vera Mandailina ${ }^{4}$, Dewi Pramita ${ }^{5}$, Habib Ratu Perwira $\mathrm{N}^{6}$ \\ 1,2,4,5 Muhammadiyah University of Mataram, Mathematic Department, \\ Jln. KH. Ahmad Dahlan, No. 1 Pagesangan, Mataram City, Indonesia \\ ${ }^{3}$ State Islamic University of Mataram, Mathematic Department \\ Jln. Gajah Mada, No. 100, Pagesangan, Mataram City, Indonesia \\ ${ }^{6}$ STMIK Bumigora of Mataram, Informatics Department, \\ Jln. Ismail Marzuki, No. 22, Cilinaya, Mataram City, Indonesia
}

\begin{abstract}
:
This study aims to develop Delphi XE8 based applications combined with Microsoft Access as a database and we call it the Digital Academic Services System (DASS), consisting of 24 Forms (GUI). We have developed this application well and received a positive response in our college. This application was developed to improve the quality of academic services for lecturers and students. Offline-based is one of the main characteristics of this application as a form of concern of the research team to students from remote areas who have inadequate internet network, but still need academic information related to their lectures. We consider this application important because the quality of academic services is determined by customer satisfaction, in this case students and lecturers as the main actors in campus activities.
\end{abstract}

Keywords: DASS, Academic Services

\section{Introduction}

The government has established a long-term education development plan that is elaborated into four themes of education development, namely (1) capacity building and modernization, strengthening services, (3) strengthening regional competitiveness, and (4) strengthening international competitiveness. Based on this, the quality and quantity of academic services in higher education has a very important role in creating professional graduates (Amin, 2017). In addition, supporting facilities that make it easier for students to access pre-school activities, during lectures, until postlectures such as student learning outcomes are needed in improving the quality of academic services (Sandhya, 2015).

The most appropriate strategy in improving the quality of academic services in higher education is to increase the existing variables in service quality, namely tangibles, reliability, responsiveness, assurance, and empathy, as evidenced by the suitability in the field, including curriculum suitability between expectations and reality, the suitability of lecture infrastructure between expectations and reality, the suitability of the implementation of lectures between expectations and facts, and the suitability of academic guidance between expectations and reality (Kar, 2016). Because service quality is a multidimensional driver of satisfaction. The level of service quality cannot be assessed based on the company's perspective but must be viewed from the point of view of the customer. Satisfaction from the consumer side is considered good if it meets what they expect, otherwise the service will be perceived as bad if it does not fulfill what they expect (Kotler, 2000: 45). Therefore, various applications are developed by each college both offline, online, or android (Roshni, 2015). All of these applications were developed to make it easier for students to access their academic activities, from taking courses to be taken in the coming semester, lecturer activities and science, lecture material, even student learning outcomes. Within the scope of higher education in Indonesia Academic Information System (AIS) was developed for individual student activities, while at the national level the government succeeded in developing the Daring E-learning System (DES). But between AIS and DES have different functions and different servers. A lot of information has not been contained 
in these two applications. Therefore, the Digital Academic Service System (DASS) is developed by connecting between the forms of AIS and DES. But we have developed it with different software, the Delphi XE8 and Microsoft Access and are offline. It is indeed not as good as the AIS and DES applications, but with simplicity it is able to make students access more data both about student data, lecturers, and academic activities.

\section{Digital Academic Service System (DASS)}

In previous studies, the research team has developed the DASS application to improve the quality of academic services to students. The coverage of menus and submenus in the DASS application is according to Table 1 below.

Table 1: Menu and Sub Menu of DASS

\begin{tabular}{|c|c|c|}
\hline No & Menu & Sub Мепи \\
\hline 1 & $\begin{array}{l}\text { Data } \\
\text { Bank }\end{array}$ & $\begin{array}{l}\text { (1) Thesis Title, (2) Course } \\
\text { Distribution, (3) Lecturer } \\
\text { Research, (4) Lecturer Service, } \\
\text { (5) Lecturer Biography, (6) } \\
\text { Study Library, (7) e-Library, (8) } \\
\text { Practicum Result Card (KHP), } \\
\text { (9) Study Result Cards (KHS), } \\
\text { and (10) Study Plan Cards } \\
\text { (KRS). }\end{array}$ \\
\hline 2 & Biodata & $\begin{array}{l}\text { (1) Management of HMPS, (2) } \\
\text { Biography of Chair Level, (3) } \\
\text { Student Biography, (4) } \\
\text { Biography of Lecturer Guardian, } \\
\text { (5) Biography of Lecturer, (6) } \\
\text { Educational Staff, (7) Graduates }\end{array}$ \\
\hline 3 & List & $\begin{array}{l}\text { (1) HMPS Management, (2) } \\
\text { Lecturer Assistant, } \\
\text { Laboratory Assistant, (4) } \\
\text { Proposal Title, (5) Proposal } \\
\text { Seminar, and (6) Thesis Exam }\end{array}$ \\
\hline 4 & $\begin{array}{l}\text { Questio } \\
\text { nnaire }\end{array}$ & Lecturer Questionnaire \\
\hline 5 & Hints & $\begin{array}{l}\text { (1) Instructions, } \\
\text { Programmers }\end{array}$ \\
\hline 6 & $\begin{array}{l}\text { Suggesti } \\
\text { on Box }\end{array}$ & Suggestion Box \\
\hline
\end{tabular}

The appearance of the Graphical User Interface (GUI) of DASS as shown in Figure 1 below,

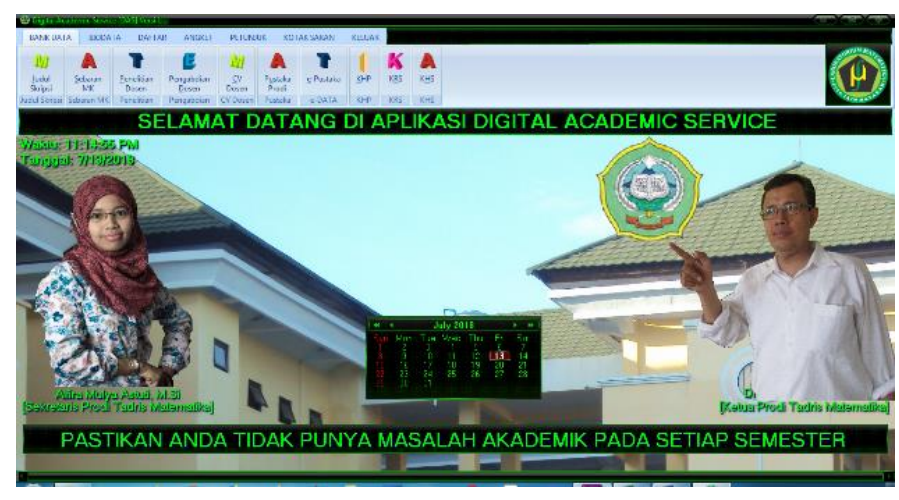

Figure 1: Main Display of DASS

\section{Method}

This research is a Research and Development $(\mathrm{R} \& D)$. That is a process used to develop and validate educational products. The steps of this process are usually referred to as the $\mathrm{R} \& \mathrm{D}$ cycle, which consists of studying research findings pertinent to the product to be developed, developing the products based on these findings, field testing it in the setting where it will be used eventually, and revising it to correct the deficiencies found in the filed-testing stage. In more rigorous programs of $\mathrm{R} \& \mathrm{D}$, this cycle is repeated until the field-test data indicate that the product meets its behaviorally defined objectives (Sugiyono, 2016). where the subject is studied the role of DASS while the object of study is the academic activities of students and lecturers through the work system of academic employees as a bridge to improve the quality and quantity of services to students. Data was collected through academic assessment questionnaires through the application of DASS by students related to the application of DASS and its benefits for the continuity of academic activities of students and lecturers. Questionnaires are arranged using a Likert Scale with 5 options. The respondents were 40 students and 10 foundation lecturers. The research procedure is in accordance with Figure 2 below. 


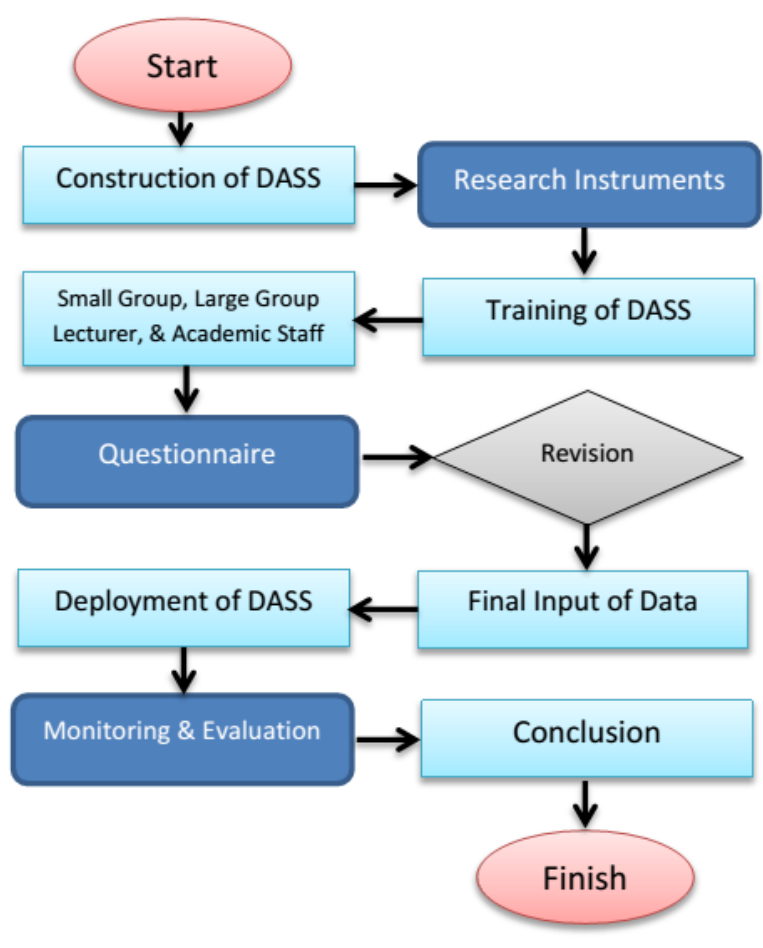

Figure 2: Research Procedure

Based on Figure 2 above, it can be seen that this study is divided into two stages, namely the stage of developing DASS applications by involving a team of experts, lecturers, students, and academic staff as assessors of the DASS application. After reaching the feasibility standard, the second stage is continued, namely the application is distributed to students in order to see the response to the use of further applications, resulting in a reliable and patent application.

\section{Result and Discussion \\ 4.1 Development Stages}

At the expert validation stage, information system experts and administrative experts give an average rating of 4,278 which means valid. The revision at this stage is in the menu that uses the regular menu, so it is revised using the Ribbon Menu which has a better display with various icon options or images on the button, the research track record and lecturer service need to be displayed, the data record must be at least five years Finally, the form display (GUI) must use the Alpha-Skins application.

Then at the development stage which consists of testing the use of applications by lecturers and students. Assessment by lecturers gave a response of $84.12 \%$ which means very good. While the assessment by students is conducted in two stages, namely small groups and large groups. In a small group trial consisting of 5 students, the average response was $87.20 \%$, which meant that the application being developed was categorized as "very good". While the large group trial consisting of 35 students obtained an average response of $88.20 \%$, which means the application being developed is categorized as "very good". The input from students is improvement on the data filter button, QReport data format that is selected from the table, usage instructions, lecturer performance forms, and some input attributes on the student biodata menu.

\subsection{Monitoring and Evaluation}

At this stage, the research team did not find a significant problem or problem, because the application of DASS that had been developed had a positive impact on improving student academic services and the average student was able to apply it well. So that at the application deployment stage in a wider scope. Students get some benefits from the application of DASS namely:

a. Facilitate the selection of course plans that will be obtained in the next semester.

b. Make it easier to prepare learning resources according to the courses taken

c. Knowing the track record of lecturer research in order to obtain research topics when compiling a thesis or final assignment

d. Make it easy to find biodata of other students for the needs of organizations or other campus activities

While at the study program level the following benefits are obtained:

a. Reducing the level of student research plagiarism with the existence of a thesis title database or previous research that has been done by previous students.

b. Easily find biodata access, lecture track record, and student organization activities

c. Facilitate the delivery of information to students.

d. Knowing the lecturers' research track record in planning future research and lecturer service plans.

e. Equalize the length of your columns on the last page. If you are using Word, proceed as follows: Insert/Break/Continuous.

\section{Conclusion}

Online or android applications do not always provide significant benefits, because to operate applications such as this requires a stable network and adequate facilities. In this world, there are still 
some areas that have not been reached by the internet network, so it requires an offline based database application that has information similar to the online or android version. Therefore, the development of various applications that aim to improve the quality of academic services do not have to use online applications, because campus residents come from various regions, both regions that have advanced with technology and some from remote areas. So that the development of offline applications is still needed.

Various activities or application development research to assist in improving the quality of academic services must continue to be carried out in order to create a stable campus atmosphere and facilitate academic and student activities. Because the quality standards of academic quality of a college are measured by the satisfaction of students, lecturers, or stakeholders in utilizing the output of the college.

\section{Acknowledgements}

The research team would like to thank the Indonesian Ministry of Research, Technology and Higher Education for providing funds for the success of this research. Then the Laboratory Assistant from Muhammadiyah University of Mataram and Mataram State Islamic University which had helped a lot during the process of developing and testing the DASS application to produce reliable products even though there were still many features that needed to be repaired. Finally to Institute for Research and Community Service of Muhammadiyah University of Mataram that has facilitated so that this activity is done well.

\section{References}

[1] D. V. K. S. Roshni Tiwari, Sonal Sharma, "Emergence of Whitespace Technology for the Creation of Super Wi-Fi Network", IJSRM, III (10), pp. 3592-3595, 2015.

[2] R. V. Sandhya Murali, "Registeration Portal for Seminar/Workshops", IJSRM, III (9), pp. 35343537, 2015

[3] S. Amin, "Strategies for Improving Academic Services in Higher Education, Jurnal Madaniyah, VII (2), pp. 222-236, 2017.

[4] S. Kar, "Usability-Based User-Centered Design of Android Applications", IJSRM, II (9), 2016.

[5] S. P. S. Manish Mishra, "Proactive Mechanism of Protection against SQL Injection Attack”, IJSRM, III (5), 2015.

[6] Sugiono, Quantitative, Qualitative Research and R \& D Methods, Alfabeta, Bandung, 2016.
[7] S. Thiagarajan, D. S. Semmel dan M. I. Semmel, Instructional Development for Training Teachers of Exceptional Children: A Sourcebook. National Center for Improvement of Educational Systems DHEW/OE. Washington, D.C, 1974

[8] Sulistiyani, S, Touchscreen Delphi XE, Wahana Komputer, Semarang, 2012

[9] Syaharuddin, et al, "JYSIM: Desktop Application to Increase Lecturer Publication Ratio", International Journal of Innovative Science, Engineering \& Technology, IV (11), pp. 197-201, 2017

[10]Syaharuddin, Mandailina, V. dan Anwar, Y. S, “ Pengembangan Software Matematika SMP/MTs Berbasis Solutif Menggunakan Borland Delphi”. Beta Jurnal Pendidikan Matematika, VIII (2), pp. 196-212, 2015

[11]Syaharuddin dan Mandailina, V, "Kombinasi Delphi dan Ms Access Dalam Perancangan Perpustakaan Digital", Jurnal Paedagoria, VIII (1), pp. 31-35, 2017.

[12]V. Ritu Sindhu, "Application and Research of Multimedia Technology in Modern Teaching”, IJSRM, III (4), 2015.

\section{Author Profile}

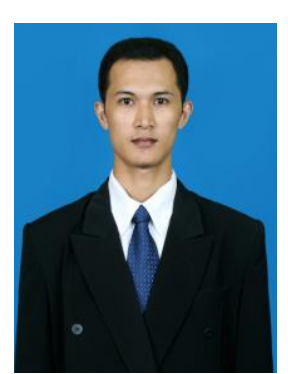

Syaharuddin, A Lecturer at the Mathematics Department of the Muhammadiyah University of Mataram, graduated from the Surabaya Institute of Technology with a concentration in Computational Mathematics. Daily activities as a Manager of the Mathematics Laboratory and National Journal Manager. Actively writing papers from the results of research funded by the Indonesian Ministry of Research, Technology and Higher Education. Research concentration in the fields of Computational Mathematics, Accounting, Modeling, Educational Technology, Learning Media. 